\title{
WALT WHITMAN AND BRAM STOKER: THE LINCOLN CONNECTION
}

\author{
ROBERT J. HAVLIK
}

BRAM STOKER acknowledged Whitman's early influence in a chapter of his book, Personal Reminiscences of Henry Irving, ${ }^{1}$ these passages have often been quoted by Whitman scholars in relation to Stoker's early correspondence with Whitman (supporting the publication of Leaves of Grass) and their first meeting in Camden in March 1884. In his chapter, however, Stoker also discusses his and Whitman's admiration for Abraham Lincoln, and he alludes to something he calls Whitman's "Message from the Dead." This "message" consisted of a letter from Whitman, along with what are supposedly Whitman's original notes for delivering his lecture on Lincoln at the Chestnut Street Opera House on 14 April 1886, documents Stoker received from Thomas Donaldson, Whitman's friend, in 1894. The recent discovery in the Rare Book Room of the University of Notre Dame library of Stoker's original manuscript for his own lecture on Lincoln ${ }^{2}$ demonstrates how his and Whitman's mutual respect for Lincoln became the major foundation of their relationship.

Stoker claims to have first become aware of Whitman and his work in 1868, when William Michael Rossetti published a volume of selections from Leaves of Grass. ${ }^{3}$ The book was widely circulated at Trinity College in Dublin, and several students managed to purchase complete editions of Leaves. Stoker, then a student at Trinity, obtained a copy and came to love it despite the derision it received from other students: "From that hour I became a lover of Walt Whitman." Stoker and a few other students gathered around Trinity professor Edward Dowden, a poet and critic who was a staunch supporter of Whitman and Leaves. On 4 May 1871, Dowden presented a paper called "Walt Whitman and the Poetry of Democracy" at the Philosophical Society, and Stoker was given the honor of opening debate on the topic. This small group of Dublin admirers stayed together for a number of years. On 18 February 1872, Stoker wrote a personal, eccentric letter to Whitman but did not send it until 14 February $1876 .{ }^{4}$

In 1871, Whitman and Tennyson had begun corresponding and on July 12, Tennyson invited Whitman to England to lecture. Dowden then wrote to Whitman asking him to prolong his stay by visiting Ireland. According to Stoker, Whitman was to stay with him while in Dublin, but due to Whitman's ill health in 1873 he was not able to make the trip. ${ }^{5}$ 
On 14 February 1876, the Fortnightly Club, a discussion group composed of Dublin men, presented a program on "The Genius of Walt Whitman" which Stoker felt was a violent attack. It was then that Stoker mailed his letter to Whitman, and the poet answered on March 6: "You did well to write me so unconventionally, so fresh, so manly, \& so affectionately too. ... . Edward Dowden's letter containing among others your subscription for a copy of my new edition, has just been rec'd. I shall send the books very soon by express in a package to his address. I have just written to E.D."6 Dowden, also stimulated by the Fortnightly Club meeting, had written for six copies of the new edition of Leaves of Grass - one of which was for Stoker - and he had also asked for Two Rivulets. ${ }^{7}$ The package that Whitman sent on March 14 is important to our story because it did contain Two Rivulets, which included Memoranda During the War on which Whitman based his lecture, "Death of Abraham Lincoln." No doubt it was in this volume where Stoker first read Whitman's description of the death of Lincoln.

Probably the most important man in Stoker's life was Henry Irving, the famous British actor, for whom Stoker served as confidant and manager from 1878 until Irving's death in 1905. Stoker traveled to America to manage Irving's acting tours, and he used those opportunities to visit many prominent literary people, including Whitman. Irving's first tour in America started in New York in October 1883. On 6 December 1883, at a dinner given for Irving at the Clover Club, Thomas Donaldson of Philadelphia gave Irving a gift-actor Edwin Forrest's watch. He also invited Irving and Stoker to his home in Philadelphia. Donaldson was a friend and benefactor of Whitman, and at his home on 20 March 1884 Whitman and Stoker finally met. At the meeting, Whitman recalled his early correspondence with Stoker and praised the Dublin group led by Dowden; he then reminisced about some of his experiences during the Civil War. Whitman invited Stoker to visit him in Camden whenever he could. One year after this meeting, on 26 March 1885, Whitman gave copies of Leaves of Grass to Donaldson for his new friends, Stoker and Irving. ${ }^{8}$

Back in England, Stoker presented a lecture, "A Glimpse of America," at the London Institution on 28 December $1885 .{ }^{\circ}$ While he did not mention Lincoln or Whitman, the seeds of his Lincoln lecture were already in this talk: "We [the British] never knew much of that war-the War of the Union-and now that the graves are hidden with 'the sweet oblivion of flowers' we can only know or guess what it was from the dry page of books and statistics of the ruin which it caused."10 Anticipating another trip to America to prepare for the 1887 Irving tour, and looking forward to visiting Whitman again, Stoker started his research on Lincoln. He began by asking Donaldson for further information on Whitman's lecture on the death of Lincoln.

Whitman had presented this lecture several times by 1886 . In an 1878 letter to Richard Watson Gilder, Whitman had agreed to prepare a lecture on 
Lincoln to be delivered on or about the anniversary of Lincoln's death, but because of illness Whitman was unable to lecture until 14 April 1879 at Steck Hall in New York. He presented a revised version a year later on 15 April 1880 at Association Hall, Philadelphia. ${ }^{11}$ This lecture, with further revisions, was presented year after year. On 11 August 1886, Whitman sent Donaldson a letter enclosing "a full report of my Lincoln lecture for your friend Bram Stoker, as you request." The enclosure consisted of "a copy of the Lincoln lecture with directions to the printer," which Whitman had corrected from a newspaper account. ${ }^{12}$

The manuscript at Notre Dame reveals that one of the Lincoln biographies Stoker had available to him was Josiah G. Holland's The Life of Abraham Lincoln, ${ }^{13}$ published within a year of Lincoln's death. Holland was the editor of Scribner's Monthly until 1881 when it was renamed Century Magazine and Richard Watson Gilder became chief editor. On 13 January 1886, Gilder initiated a scheme to purchase the original cast of the Leonard Wells Volk life-mask of Lincoln for presentation to the Smithsonian. The money was to be raised by offering subscriptions to a limited number of copies of the mask to be re-cast either in bronze or plaster by Augustus SaintGaudens. Invitations to subscribe to the casts were probably sent to Henry Irving and Bram Stoker in January 1886 since both men eventually became subscribers. The invitation from Gilder may have been another incentive for Stoker to write about Lincoln.

Stoker left London for New York on 23 October 1886. While on the ship he began writing his lecture on Lincoln-one of the original drafts is dated 28/10/86. He arrived in New York on October 31, and on November 2 he went to Philadelphia on business. Later that day he and Donaldson traveled to Camden. Stoker reported that Whitman was genuinely glad to see him, and after some talk about Henry Irving, the conversation took an interesting turn: "Our conversation presently drifted toward Abraham Lincoln for whom he had an almost idolatrous affection. I confessed that in this I shared and it was another bond between us. He said: 'No one will ever know the real Abraham Lincoln or his place in history." 14 In his lecture, Stoker would incorporate and extend Whitman's statement: "Not long since Walt Whitman said to me: 'No man knows-no one in the future can ever know Abraham Lincoln. He was much greater-so much vaster even than his surroundings - what is not known of him is so much more than what is, that the true man can never be known on earth.'"

During this conversation Stoker learned more from Whitman about the poet's imagined experience at the time of Lincoln's death (Whitman was actually in New York when Lincoln was shot):

I had of course read his wonderful description of the assassination by Wilkes Booth given in his Memoranda During the War, published in the volume called Two Rivulets in the Centennial Edition of his works in 1876 . This is so startlingly vivid that I thought that the man who had 
written it could tell me more. So I asked him if he were present at the time. He said: "No, I was not present at the time of the assassination; but I was close to the theatre and was one of the first in when the news came. Then I afterwards spent the better part of the night interviewing many of those who were present and of the President's Guard, who, when the terrible word came out that he had been murdered, stormed the house with fixed bayonets. It was a wonder that there was no holocaust, for it was a wild frenzy of grief and rage. It might have been that the old sagas had been enacted again when amongst the Vikings a Chief went to Valhalla with a legion of spirits around him!"15

Stoker's lecture would culminate with a description of Lincoln's assassination that begins by acknowledging that "Walt Whitman describes what followed." Then Stoker quotes extensively from pages forty-seven to fortynine of Memoranda During the War, beginning with the sentence "The stage was clear for a moment, ..." and ending with "... the life blood from those veins the best and sweetest of the land drips slowly down." Two handwritten copies of these quotations are part of the Stoker manuscript, one edited out and abandoned, the other edited during copying with later deletions for various presentations. Stoker ends this long quotation by again saying, "Such is Walt Whitman's account of the murder," and he concludes by citing Whitman's assessment of Lincoln, quoted above.

After the Camden meeting, Stoker went to New York where he visited Saint-Gaudens to see if he would execute a bust of Whitman. Saint-Gaudens was enthusiastic, and on November 8 and 9, when Stoker was back in Philadelphia, he arranged with Donaldson to form a group to fund SaintGaudens's out-of-pocket expenses for casting a bronze bust. But because of Whitman's stroke in 1888 and Saint-Gaudens's inability to get to Philadelphia, the project was never completed. The idea, though, obviously derived from Richard Watson Gilder's formation of a group to purchase the Lincoln life mask and to have copies made by Saint-Gaudens. Stoker states:

He [Saint-Gaudens] was at that time very busy with his great statue of Abraham Lincoln for Chicago. Incidentally I saw in his studio the life mask and hands of Lincoln made by the sculptor Volk before he [Lincoln] went to Washington for his first Presidency. The mould had just been found by the sculptor's son twenty-five years after making. Twenty men joined to purchase the models and present them to the nation. Saint-Gaudens made casts in bronze of the face and hands with a set for each of the twenty subscribers with his name in each case cut in the bronze. Henry Irving and I had the honor of being two of the twenty. The bronze mask and hands, together with the original plaster moulds, rest in the Smithsonian Institute in Washington with a bronze plate recording the history and the names of the donors. I felt proud when, some years later, I saw by chance my own name in such a place, in such company, and for such a cause. ${ }^{16}$

Stoker returned to England and perhaps delivered his Lincoln talk there. He then came back to America in the fall of 1887, when Irving opened his second American tour, and on 25 November he gave his lecture in New York City. The review the next day in the New York Times was not very complimentary: 
Less than 100 people listened to a lecture by Bram Stoker yesterday afternoon in Chickering Hall, the subject being 'Abraham Lincoln.' Mr. Stoker has delivered this lecture with great acceptance before unenlightened English audiences, and his utterances have been highly commended by the semi-educated English press. On this side of the water, however, where Abraham Lincoln lived and died, and where American history is taught in public schools, a historical review of the life and times of the martyr-President, even when presented by Mr. Henry Irving's manager, is apt to fall flat.

General Horace Porter, who was an apparently interested auditor, congratulated Mr. Stoker at the conclusion of the lecture, and Major Pond, as he gazed sadly around the vast array of empty seats, said: "Well, I didn't expect any thing else. This lecture was advertised just as extensively as the readings of Charles Dickens or the talk of Max O'Reil. I spent just as much money on it. Mr. Stoker showed me some very flattering notices of his lecture clipped from the English press. So I said to him one day, "Why dont you deliver that lecture in New York, Stoker!' The fact is," said the Major, reflectively, "nobody cares to listen to a lecture on Abraham Lincoln in this country." "Say," suddenly cried the Major, brightening up like a May moon all in an instant, "how would it do to have Rider Haggard come over here and read portions of a new unpublished novel in Chickering Hall, eh!" The Major's chuckles as he turned this happy thought over in the gray matter of his brain were plenty audible in Union square. ${ }^{17}$

Stoker may have been embarrassed by the review, since when he next visited Whitman on 22 December 1887 he apparently did not discuss his lecture. Instead, in an apparent change of heart from his youthful unqualified defense of Leaves of Grass, he focused on his request that Whitman consider cutting about one hundred lines from his book. In his Reminiscences, in a section oddly titled "Responsibility," Stoker states:

In the meantime I had much conversation about Walt Whitman with many of his friends. The week after my last interview, I had been again in Philadelphia for a day, on the evening of which I had dined with his friend and mine, Talcott Williams of the "Press." During the evening we talked much of Walt Whitman, and we agreed that it was a great pity that he did not cut certain lines and passages out of the poems. Talcott Williams said he would do it if permitted, and I said I would speak to Walt Whitman about it whenever we should meet again. The following year, 1887, I breakfasted with Talcott Williams, 19th December, and in much intimate conversation we spoke of the subject again.

\section{The two men later visited Whitman in his home:}

I ventured to speak to him what was in my mind as to certain excisions of his work. I said: "If you will only allow your friends to do this - they will only want to cut about a hundred lines in all-your books will go into every house in America. Is not that worth the sacrifice?" $\mathrm{He}$ answered at once, as though his mind had long ago been made up and he did not want any special thinking: "It would not be any sacrifice. So far as I am concerned they might cut a thousand. It is not that-it is quite another matter:" - here both face and voice grew rather solemn - "when I wrote as I did I thought I was doing right and right makes for good. I think so still. I think that all that God made is for good - that the work of His hands is clean in all ways if used as $\mathrm{He}$ intended! If I was wrong I have done harm. And for that I deserve to be punished by being forgotten! It has been and cannot-not-be. No, I shall never cut a line so long as I live!"18

Whitman kept his word as he made no changes after the 1881 edition of Leaves of Grass. 
At the conclusion of their meeting Whitman gave Stoker and Donaldson two gifts, a signed photograph (taken by Gutekunst of Philadelphia) and an autographed 1872 edition of As a Strong Bird on Pinions Free with the admonition, "Take these and keep them from me and Goodbye!" This was the last time Stoker saw Whitman.

Stoker did not return to America between the spring of 1888 and early fall 1893; however, he continued to present his lecture in England. The Notre Dame manuscript contains numerous variations and corrections, especially of the introductory pages, to adapt the lecture to various audiences, and later to acknowledge the death of Whitman.

Stoker was once more in America in 1893 when Irving opened his next American tour at the Grand Opera House in San Francisco. But not until 4 February 1894 did Stoker reach Philadelphia and visit Donaldson. Stoker describes the visit as follows:

Shortly after I came in he went away for a minute and came back with a large envelope which he handed to me: 'That is for you from Walt Whitman. I have been keeping it till I should see you.' The envelope contained, in a rough card folio, pasted down on thick paper, the original notes from which Whitman delivered his lecture on Abraham Lincoln at the Chestnut Street Opera House on April 15, 1886. With it was a letter to Donaldson, in which he said: 'Enclosed I send a full report of my Lincoln Lecture for our friend Bram Stoker.' This was my Message from the Dead. ${ }^{19}$

Why Donaldson had not given this to Stoker in October 1886 when he visited him (since he had it in his possession in August 1886), but instead waited over seven years, is unknown.

Neither do we know if Stoker delivered his lecture again. By 1894, in addition to his duties as Irving's manager for three more tours of America and one of Canada, he was very much involved with his novels and short stories. Between 1889 and 1914 he published fifteen books, the last posthumously; the most famous, Dracula, was published in 1897. ${ }^{20}$ After Irving died in 1905 Stoker wrote the two-volume Personal Reminiscences of Henry Irving which was more revealing of his own personality than of the actor's.

Stoker died on 21 April 1912, possibly of tertiary syphilis. ${ }^{21}$ On 20 June 1913, the Times of London announced that Stoker's library would be sold, and a "Catalog of printed books autographed letters and illustrated and other manuscripts including the library of the late Bram Stoker" was issued. ${ }^{22}$ The casts of the mask and hands sold for $£ 16$ 10s. The London Daily Telegraph commented on the apparent lack of interest in Whitman's manuscripts:

Seven years ago there was a fight at Sotheby's for the three notebooks by Shelley, and an agent of an America bibliophile won them for $£ 3000$. Yesterday, in the same rooms, a collection of fragments in the hand of Walt Whitman, the 'poetic celebrant of Democracy,' came up, and the last word was only $£ 1610$ s. The remainder of Shelley's scrapbooks are in the Bodleian. How long will it take for Whitman's literary fragments to get to Yale or Harvard? ${ }^{23}$ 
The Whitman letter was again sold on 1 May 1917 for $\$ 91.00$. A description of the manuscript as reported in America Book Prices Current indicates that the Stoker manuscript was a copy for the printer:

\section{Whitman (Walt)}

Autograph Manuscript of his 'Lecture on Abraham Lincoln, Delivered in Chestnut Street Opera House, Philadelphia, on April 15, 1886.' Copy for the printer, with many corrections and additions in Whitman's hand. Mounted on $5 \frac{1}{2} 2$ pages, royal 8 vo, cardboard. With A.L.S. 1 page, 4to, Camden, Aug 11 [1886] enclosing a report of the lecture to Bram Stoker.

Bell, A., May 1, '17. (641A) $\$ 91.00^{24}$

This manuscript clearly is not the same one that sold for $\$ 120.00$ on 14 January 1914:

Whitman (Walt)

Original Autograph of his lecture 'Death of Abraham Lincoln (written Feb. 1879).' Written on many slips of paper and mounted on 17 leaves. With Proof portraits of Lincoln and Whitman, that of Whitman being signed Walt Whitman, June 9, ' 86 . 4to, bound in hf. mor., gt. A ticket advertising the lecture, autographed by Jacques Reich, the artist who drew the portrait of Lincoln, laid in.

Lambert, A. Jan. 14, '14. (1001) $\$ 120.00^{25}$

The discovery of the University of Notre Dame Stoker/Lincoln manuscript shows that the strongest bond between Bram Stoker and Walt Whitman was a mutual interest in Lincoln. While Stoker apparently became less enamored of Leaves of Grass over time, eventually asking Whitman to edit the book to make it more palatable to the public, his interest in Lincoln did not lag but rather continued for many years after Whitman's death.

\section{University of Notre Dame}

\section{NOTES}

1 Bram Stoker, Personal Reminiscences of Henry Irving (New York: Macmillan, 1906), 2:92-111.

2 The volume is an original autograph of Stoker's Lecture on Abraham Lincoln, dated 1888, written on sheets of $9 \times 11$ paper, mounted on 156 leaves. Included is a letter by Lord Walter Frewen dated 7 April 1889, and a ticket to Stoker's lecture, Abraham Lincoln, at Toynbee Hall, dated 14 January 1893. Also laid in is a broadside advertising a lecture by Stoker, On Abraham Lincoln: how the Statesman of the People saved the Union, and abolished Slavery in the American Civil War, which was presented on 16 December 1888 at the Sunday Lecture Society. The leaves are bound quarto in red buckram, with gilt edges and lettering. The volume is organized with "First Notes" followed by the lecture itself with some pages heavily edited and others clear but showing evidence of having been copied at different periods. The main lecture is followed by two sections of variant portions of the lecture. Included are numerous variations of his opening page in which the introduction was edited for American and English audiences as well as for various dates of presentation. 
4 Edwin Haviland Miller, ed., Walt Whitman: The Correspondence, 6 vols. (New York: New York University Press, 1961-1977), 3:28n.

5 Stoker, Irving, 2:98.

6 Miller, 3:28.

7 Miller, 3:26.

8 Miller, 4:41.

9 Bram Stoker, A Glimpse of America: A Lecture given at the London Institution, 28 December 1885 (London: S. Low, Marston and Co., 1886).

10 Stoker, Glimpse, 39-40. Besides A Glimpse of America Stoker had two other publications before he went to America on his first visit: Duties of Clerks of Petty Sessions in Ireland (1878) and Under Sunset (1882), a collection of children's fantasies that foretold his later Gothic novels.

11 See Roy P. Basler, ed., Walt Whitman's Memoranda During the War E' Death of Abraham Lincoln, reproduced in facsimile (Bloomington: Indiana University Press, 1962), 33.

12 Miller, 3:176; 4:40-41.

13 Josiah G. Holland, The Life of Abraham Lincoln (Springfield, MA: G. Bill, 1866).

14 Stoker, Irving, 2:103.

15 Stoker, Irving, 2:103.

16 Stoker, Irving, 2:109. Stoker is not quite accurate here. Correspondence in the Smithsonian shows there were thirty individual subscribers and three institutions. The original casts were turned over to the Smithsonian on 19 January 1888, and they were accessioned and all contributions acknowledged on January 25 . The casts were, however, available to subscribers by February 1886. In the Notre Dame manuscript, Stoker added a note to one version of the lecture indicating that he had the mask with him and displayed it when describing Lincoln's physical features.

17 New York Times, 26 November 1887.

18 Stoker, Irving, 2:106-107.

19 Stoker, Irving, 2:111.

20 For a discussion of Whitman's possible influence on Dracula, see Dennis R. Perry, "Whitman's Influence on Stoker's Dracula," Walt Whitman Quarterly Review, 3 (Winter 1986), 29-33.

21 Daniel Farson, The Man Who Wrote Dracula: A Biography of Bram Stoker (London: Joseph, 1975), 233.

22 Two other London Times reports concerned the sale of the Stoker collection: Times, 20 June 1913; Times, 8 July 1913.

23 “Walt Whitman's Mss.," London Daily Telegraph, 8 July 1913.

24 American Book Prices Current, 1917 (Autographs and Manuscripts), 1073.

25 American Book Prices Current, 1914. This MS may be the copy which was reproduced in the Basler volume (identified as part of the Feinberg Collection) since a reproduction of a ticket to the 15 April 1886 lecture is printed in the book along with Whitman's revised introduction for that date; see Basler, 39. 